to study their patients. We are indebted to $\mathrm{Mr} M$ Haddon for laboratory help; Mrs M Jefferies, who helped prepare the data for analysis; and Mrs J Rose, Mrs V Calder, Mrs P Vaughton, and Mrs R Alexander for clinical help.

\section{References}

${ }^{1}$ Bonnar, J, McNicol, G P, and Douglas, A S, British Medical fournal, 1971 2,12 .

2 Henderson, A H, Pugsley, D J, and Thomas, D P, British Medical fournal, $1970,3,545$.

${ }^{3}$ Howie, P W, et al, Lancet, 1976, 2, 323.

${ }^{4}$ Gordon, Y B, et al, British fournal of Obstetrics and Gynaecology, 1976, 83, 287.
${ }^{5}$ Naish, P, et al, Obstetrics and Gynecology, 1973, 42, 861.

6 Condie, R G, British fournal of Obstetrics and Gynaecology, 1976, 83, 636

${ }^{7}$ Redman, C W G, Beilin, L J, and Bonnar, J, fournal of Clinical Pathology, 1976, 29, suppl No 10, p 91 .

${ }^{8}$ Butler, N R, and Bonham, D G, in Perinatal Mortality, p 86. Edinburgh, $\mathrm{E}$ and $\mathrm{S}$ Livingstone, 1963.

9 Redman, C W G, et al, Lancet, 1976, 1, 1370.

10 Bull, B S, Schneiderman, M A, and Brecher, G, American fournal of Clinical Pathology, 1965, 44, 678.

11 Sejeny, S A, Eastham, R D, and Baker, S R, fournal of Clinical Pathology, $1975,28,812$.

${ }^{12}$ Fenton, V, Saunders, K, and Cavill, I, fournal of Clinical Pathology, 1977, 30, 68.

13 Sheppard, B L, and Bonnar, J, British fournal of Obstetrics and Gynaecology, 1976, 83, 948

(Accepted 14 December 1977)

\title{
Duodenal ulcer and working-class mobility in an African population in South Africa
}

\author{
ISIDOR SEGAL, ALLIE A DUBB, LEONARD OU TIM, A SOLOMON, \\ MANUEL C C G SOTTOMAYOR, ESTHER M ZWANE
}

British Medical fournal, 1978, 1, 469-472

\section{Summary and conclusions}

The number of Africans in Johannesburg presenting with duodenal ulcers has steadily increased over the past 50 years. The characteristics of 105 patients with duodenal ulcer who presented at Baragwanath Hospital were compared with those of matched and unmatched samples of patients without gastrointestinal conditions in the same hospital. Men with duodenal ulcers were found to be significantly better educated than their controls, most had been born in the town, and more of them were employed at higher, though not the highest, educational levels.

These data were used to test Susser's proposition that duodenal ulcers are associated with "early urbanisation." Johannesburg blacks with duodenal ulcer did seem to fit the pattern, but the relation between stress and duodenal ulcer remains unclear.

\section{Introduction}

Duodenal ulcer is rarely reported in the rural black population of South Africa. ${ }^{1}$ Until recently this was also true among urban blacks: Beyers ${ }^{2}$ reported only three cases among 18000 hospital

Gastroenterology Unit, Baragwanath Hospital and University of the Witwatersrand, Johannesburg, South Africa

ISIDOR SEGAL, MB, MRCP, senior physician

LEONARD OU TIM, MB, FCP(SA)

MANUEL C C G SOTTOMAYOR, LMC(PORTO), PHD

African Studies Institute, University of the Witwatersrand, Johannesburg, South Africa

ALLIE A DUBB, MA, PHD, associate professor and director ESTHER M ZWANE, RN, research assistant

Department of Radiology, Baragwanath Hospital and University of the Witwatersrand, Johannesburg, South Africa

A SOLOMON, MB, MMED RAD(D), professor and chief radiologist admissions in Johannesburg in 1921-6 (0.02\%). There has, however, been a steady increase in the number of cases over the past 50 years. Thus Eagle and Gillman ${ }^{3}$ found 13 cases of duodenal ulcer in 9472 necropsies performed in 1928-37 $(0 \cdot 14 \%)$; Bremner ${ }^{4}$ reported 87 cases among $31500(0 \cdot 28 \%)$ admissions to the surgical section of the Johannesburg General Hospital in 1964-71; and in 1976105 patients with newly diagnosed duodenal ulcer were admitted to Baragwanath Hospital medical and surgical wards out of a total of 23244 adult admissions $(0.45 \%)$. We examined some of the characteristics of these urban black patients and compared them with selected control groups. We propose here some hypotheses that may explain any differences noted. Our study was thus exploratory rather than definitive.

\section{Patients and methods}

The series consisted of the 105 patients who presented, either as inpatients or outpatients, at Baragwanath Hospital, Johannesburg, during 12 months in 1976-7 and who were found to have duodenal ulcers. Diagnosis was based on clinical and radiological examination and, in most cases, endoscopy. Thirty-five of the patients, who were available either as inpatients or outpatients over four weeks in 1976, were subjected to more intensive interviewing by a physician and, separately, by a trained sister under the direction of a social anthropologist. The detailed findings relating to this subgroup will be presented in another paper, though some of the data are presented here.

One hundred and five patients without traumatic or gastrointestinal conditions were matched with the patients for age, sex, and inpatient or outpatient status. They were selected and substituted (as control quotas were filled) at random, and were interviewed over three weeks in August and September 1977. A second unmatched control group was interviewed over one week in September 1977. We wanted equal numbers of men and women and excluded those with trauma or gastrointestinal conditions, but otherwise the unmatched controls were selected at random. The final sample comprised 33 men and 35 women.

Several questionnaires were used. These included the medical officer's schedule (short), the medical officer's schedule (long), the sociological schedule, and an anxiety schedule (to which were added, when administered alone, several biographical questions). All but the sociological schedule were highly structured. The sociological schedule, however, comprised a number of open-ended questions, and interviews were conducted as informally as possible. Anxiety was measured by the Taylor Manifest Anxiety scale ${ }^{5}$ adapted by $\mathrm{Mr}$ 
David White, Human Resources Laboratory of the Chamber of Mines, Johannesburg, and translated under his supervision into four African languages for use with black miners. We used the preliminary results of the study among the miners for comparison with our own results.

Not all patients were assessed on all the schedules. The 105 matched controls and 70 of the patients with duodenal ulcer were assessed by the medical officer's short schedule, while the remaining 35 patients with ulcer underwent more intensive investigation with the medical officer's long schedule and the sociological and anxiety schedules. The unmatched controls were assessed for anxiety and asked biographical questions.

\section{Background}

Johannesburg is the largest city in South Africa. It has a population of 1.5-1.75 million, about 1 million of whom are Africans. ${ }^{6}$ The city was founded 90 years ago as a mining camp, and expanded rapidly not only as the centre of the gold-mining industry but also as the commercial and secondary industrial hub of southern Africa. The major ethnic cleavages characterising all aspects of life in South Africa are reflected in the residential, occupational, and economic patterns of Johannesburg. Thus most blacks are legally regarded as temporary migrants rather than as permanent city dwellers; they live on the outskirts of Johannesburg in vast mass-housing complexes such as Soweto; and they are usually employed in the least-skilled and lowest-paid jobs, though some are gradually emerging from this condition.

The black population of Soweto is made up of members of all tribal groups in South Africa and its neighbouring states. It includes adherents of ancestor religion, "orthodox" Christianity, and a myriad of Christian and quasi-Christian sects. There are the urban born and bred, the immigrants of 30,40 , and 50 years' standing, and the migrants who return each year to their families in the rural areas for shorter or longer periods. And, finally, there are the city slickers, the sophisticated socialites, the barely educated, and the illiterate men from the country. It is, then, a complex, polyglot population, largely immigrant, and mainly lower working class, but with an emerging highly urbanised, better-trained, upper working class and middle class.

Health care for the half million blacks of Soweto is provided by the traditional sangomas (diviners) and inyangas (herbalists), Christian faith-healers, private doctors, and by Baragwanath Hospital and its network of clinics.

The relevance of the present state of upheaval in Soweto, which began in mid-June 1976, to our study is probably minimal except possibly in relation to the level of anxiety.

TABLE I-Sex and age structure of the three groups and population of Soweto

\begin{tabular}{|c|c|c|c|c|c|c|c|}
\hline Age (years): & $15-19$ & -29 & -39 & -49 & -59 & -69 & Total \\
\hline \multicolumn{8}{|c|}{ Men } \\
\hline $\begin{array}{l}\text { Patients with ulcer*† } \\
\text { Matched controls } \\
\text { Unmatched controls* } \\
\text { Population }{ }^{*}\end{array}$ & $\begin{array}{l}2 \\
2\end{array}$ & \begin{tabular}{|c}
24 \\
24 \\
8 \\
83280
\end{tabular} & $\begin{array}{c}9 \\
10 \\
7 \\
66866\end{array}$ & $\begin{array}{c}17 \\
16 \\
6 \\
58 \stackrel{891}{ }\end{array}$ & $\begin{array}{c}14 \\
15 \\
5 \\
35453\end{array}$ & $\begin{array}{c}7 \\
7 \\
7 \\
16580\end{array}$ & $\begin{array}{c}73 \\
74 \\
33 \\
261070\end{array}$ \\
\hline \multicolumn{8}{|c|}{ Women } \\
\hline $\begin{array}{l}\text { Patients with ulcer } \ddagger \S \\
\text { Matched controls } \\
\text { Unmatched controls } \ddagger \\
\text { Population } \S\end{array}$ & & \begin{tabular}{|c}
9 \\
9 \\
9 \\
71093
\end{tabular} & \begin{tabular}{|c|}
13 \\
12 \\
8 \\
63247
\end{tabular} & $\begin{array}{c}8 \\
9 \\
7 \\
45367\end{array}$ & $\begin{array}{c}2 \\
1 \\
7 \\
24\end{array}$ & $\begin{array}{c}4 \\
14837\end{array}$ & $\mid \begin{array}{c}32 \\
31 \\
35 \\
218650\end{array}$ \\
\hline
\end{tabular}

${ }^{*} \chi^{2}=4.49 ; \mathrm{DF}=4 ; \mathrm{P}<0.5$ (NS).

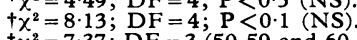

$+\chi^{2}=7 \cdot 37 ; \mathrm{DF}=3$ (50-59 and 60-69 combined); $\mathrm{P}<0 \cdot 1$ (NS)

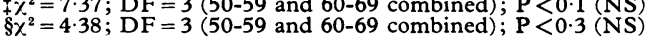

\section{Results}

The main characteristics of black patients with duodenal ulcer are presented in tables I-VII.

Sex-Twice as many men as women had duodenal ulcer $(2 \cdot 3: 1)$, though the sex ratio in the total population was $1 \cdot 1: 1$ (table I).

Age-Although patients with ulcer seemed to be younger than the unmatched controls and the total black population, the $\chi^{2}$ test indi- $\breve{.}$ cated that the differences were not statistically significant (table I).

Ethnic group-There was no indication that any ethnic group was more or less susceptible to duodenal ulcer, although for some unknown reason there seemed to be a disproportionately large number of Swazi patients in both the duodenal ulcer and control groups (table II).

Place of birth and urban residence-There was no significant difference between the two groups of women (table III). But significantly more men with duodenal ulcer were born in town than those in the $\vec{O}$ matched control group, while significantly fewer patients with ulcers had lived in Johannesburg for under 20 years.

TABLE III-Place of birth and length of residence in fohannesburg

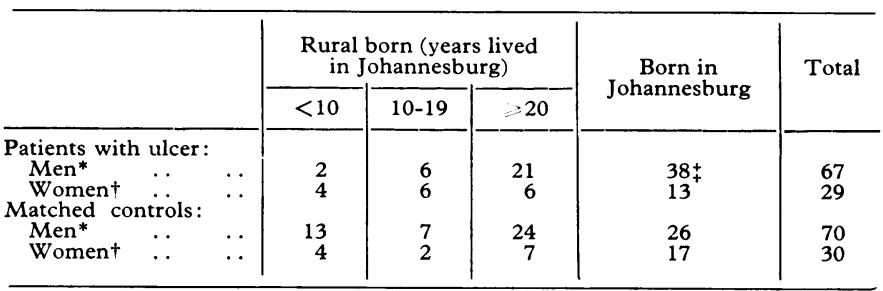

${ }^{*} \chi^{2}=10.53 ; \mathrm{DF}=3 ; \mathrm{P}<0.02 . \quad+\chi^{2}=1.59 ; \mathrm{DF}=2 ; \mathrm{P}<0.5(\mathrm{NS})$

+Includes 4 born in another urban area.

TABLE IV-Degree of education in each group according to sex

\begin{tabular}{|c|c|c|c|c|}
\hline Level of schooling: & None & Primary & $\begin{array}{c}\text { Secondary } \\
\text { and } \\
\text { beyond }\end{array}$ & Total \\
\hline \multicolumn{5}{|c|}{ Men } \\
\hline $\begin{array}{l}\text { No }(\%) \text { of patients with ulcer*† } \\
\text { No }(\%) \text { of matched controls**+ } \\
\text { No }(\%) \text { of unmatched controls } \dagger_{+}^{+}\end{array}$ & $\begin{array}{l}6(8) \\
15(20) \\
10(30)\end{array}$ & $\begin{array}{l}21(29) \\
33(45) \\
11(33)\end{array}$ & $\begin{array}{l}46(63) \\
26(35) \\
12(36)\end{array}$ & $\begin{array}{l}73(100) \\
74(100) \\
33(99)\end{array}$ \\
\hline \multicolumn{5}{|c|}{ Women } \\
\hline $\begin{array}{l}\text { No }(\%) \text { of patients with ulcer } \\
\text { No }(\%) \text { of matched controls } \S \uparrow \\
\text { No }(\%) \text { of unmatched controls }\end{array}$ & $\begin{array}{l}1(3) \\
4(13) \\
2(6)\end{array}$ & $\begin{array}{r}7(22) \\
9(29) \\
21(60)\end{array}$ & $\begin{array}{l}24(75) \\
18(58) \\
12(34)\end{array}$ & $\begin{array}{l}32(100) \\
31(100) \\
35(100)\end{array}$ \\
\hline
\end{tabular}

${ }^{*} \chi^{2}=12.07 ; \mathrm{DF}=2 ; \mathrm{P}<0.01 . \quad \dagger \chi^{2}=10.46 ; \mathrm{DF}=2 ; \mathrm{P}<0.01$.

$\chi^{2}=1 \cdot 7 ; \mathrm{DF}=2 ; \mathrm{P}<0.5$ (NS). $\$ \chi^{2}=2 \cdot 03 ; \mathrm{DF}=1 ; \mathrm{P}<0.2$

Education-Men with duodenal ulcer were significantly better educated than men in either of the control groups (table IV). Women $\sigma$ with ulcers did not differ significantly from their matched controls but were better educated than the unmatched controls.

Occupation-There were no significant differences in occupation $N$ among the three groups of women (table V). But among the men with $N$ duodenal ulcer there were significantly more professional, technical, $\omega$ clerical, and transport (drivers) workers and fewer production workers than in. either control group (table VI). Furthermore, though this is $\stackrel{0}{ }$ not reflected in table $\mathrm{V}$, five of the 22 production workers with duodenal $\Phi$ ulcer were supervisors compared with one out of 42 in the matched $\stackrel{?}{+}$ control group and none in the unmatched group.

Anxiety-There were no significant differences between men and

\begin{tabular}{|c|c|c|c|c|c|c|c|c|c|c|}
\hline & & Zulu & Tswana & S Sotho & Xhosa & Pedi & Swazi & Other & Total & Unknown \\
\hline $\begin{array}{l}\text { No }(\%) \text { of patients with ulcer*t } \\
\text { No }(\%) \text { of matched controls* } \ldots \\
\% \text { of Soweto population }{ }^{\dagger}\end{array}$ & $\begin{array}{l}\cdots \\
\cdots\end{array}$ & $\begin{array}{c}19(23) \\
33(31) \\
30\end{array}$ & $\begin{array}{c}21(26) \\
14(13) \\
18\end{array}$ & $\begin{array}{c}14(17) \\
22(21) \\
12\end{array}$ & $\begin{array}{c}5(6) \\
16(15) \\
10\end{array}$ & $\begin{array}{c}5(6) \\
6(6) \\
10\end{array}$ & $\begin{array}{l}9(11) \\
7(7)\end{array}$ & $\begin{array}{l}8(10) \\
7(7) \\
20+\end{array}$ & $\begin{array}{c}81(100) \\
105(100) \\
100(819706)\end{array}$ & 24 \\
\hline
\end{tabular}

$* \chi^{2}=10 \cdot 19 ; \mathrm{DF}=6 ; \mathrm{P}<0.2$ (NS). $\quad+\chi^{2}=9 \cdot 43 ; \mathrm{DF}=5 ; \mathrm{P}<0.1$ (NS).

\pm Includes Swazi. 
women in any of the groups, nor did men in the two groups differ (table VII). Women in the control group were significantly more anxious than women suffering from duodenal ulcers. The most striking, and statistically significant, differences were, however, between patients with ulcers and the control group, on the one hand, and a sample of male African mineworkers, on the other. This can probably be explained by the fact that the miners were tested before the Soweto riots and that in any case they lived in a relatively insulated environment and were a normally healthy group. By contrast, both the patients with duodenal ulcer and the controls were tested during the continuing events in Soweto and while they were undergoing medical treatment. The anxiety test did not enable us to show whether or not patients with duodenal ulcers were relatively more anxious or tense.

\section{Discussion}

Several factors are thought to be jointly implicated in causing duodenal ulcers. Susser has suggested that one of these factors may be urbanisation. ${ }^{7} \mathrm{He}$ argues that duodenal ulcer "could be a disease of an early phase of urbanisation" and that its decline in the West may have occurred because "large sections of the population may by now have learnt to adapt to the demands of industrial society, so that these are felt as less stressful than

TABLE V-Occupation in each group according to sex

\begin{tabular}{|c|c|c|c|c|c|c|}
\hline \multirow[b]{2}{*}{ Occupation } & \multicolumn{3}{|c|}{ Men } & \multicolumn{3}{|c|}{ Women } \\
\hline & $\begin{array}{l}\text { Patients } \\
\text { with } \\
\text { ulcer }\end{array}$ & $\begin{array}{l}\text { Matched } \\
\text { controls }\end{array}$ & $\begin{array}{l}\text { Unmatched } \\
\text { controls }\end{array}$ & $\begin{array}{l}\text { Patients } \\
\text { with } \\
\text { ulcer }\end{array}$ & $\begin{array}{l}\text { Matched } \\
\text { controls }\end{array}$ & $\begin{array}{c}\text { Unmatched } \\
\text { controls }\end{array}$ \\
\hline 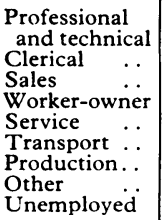 & $\begin{array}{r}4 \\
17 \\
4 \\
1 \\
8 \\
10 \\
22 \\
1 \\
6\end{array}$ & $\begin{array}{r}2 \\
15 \\
1 \\
11 \\
1 \\
42 \\
1 \\
1\end{array}$ & $\begin{array}{r}3 \\
1 \\
1 \\
5 \\
2 \\
16 \\
1 \\
4\end{array}$ & $\begin{array}{r}7 \\
2 \\
2 \\
1 \\
7 \\
10 \\
10 \\
3\end{array}$ & $\begin{array}{r}12 \\
7 \\
5\end{array}$ & $\begin{array}{r}1 \\
2 \\
15 \\
4 \\
13\end{array}$ \\
\hline Total $\ldots$ & 73 & 74 & 33 & 32 & 31 & 35 \\
\hline
\end{tabular}

TABLE VI-Statistical comparison of occupations between the three groups

\begin{tabular}{|c|c|c|c|c|}
\hline & & $x^{2}$ & DF & $P$ value \\
\hline \multicolumn{5}{|c|}{ Men } \\
\hline $\begin{array}{l}\text { Patients with ulcer } v \text { matched controls } \\
\text { Patients with ulcer } v \text { unmatched controls } \\
\text { Matched controls } v \text { unmatched controls }\end{array}$ & \begin{tabular}{l|l}
$\cdots$ \\
$\cdots$ \\
$\cdots$
\end{tabular} & $\begin{array}{l}9 \cdot 47 \\
7 \cdot 50 \\
0 \cdot 39\end{array}$ & $\begin{array}{l}2^{*} \\
1+ \\
1+\end{array}$ & $\begin{array}{l}<0.01 \\
<0.01 \\
<0.7 \text { (NS) }\end{array}$ \\
\hline \multicolumn{5}{|c|}{ Women } \\
\hline $\begin{array}{l}\text { Patients with ulcer } v \text { matched controls } \\
\text { Patients with ulcer } v \text { unmatched controls } \\
\text { Matched controls } v \text { unmatched controls }\end{array}$ & \begin{tabular}{l|}
$\cdots$ \\
$\cdots$ \\
$\cdots$
\end{tabular} & $\begin{array}{l}2 \cdot 10 \\
1 \cdot 82 \\
2 \cdot 12\end{array}$ & $\begin{array}{l}2 * \\
1+ \\
1+\end{array}$ & $\begin{array}{l}<0.5 \text { (NS) } \\
<0.2 \text { (NS) } \\
<0.2 \text { (NS) }\end{array}$ \\
\hline
\end{tabular}

*Professional, technical, clerical, and transport workers were grouped together and compared with service workers and production workers. Other groups were ignored. one category. before." He suggests that men of the higher social classes were first affected by the rise in the prevalence of the disease early in the century, but that the working classes suffered increasingly in later decades. Susser has not attempted to explain the trends he describes and leaves some of the crucial questions unanswered: What is the nature of the implied connection between urbanisation, stress, and duodenal ulcer ? Do some types of psychological stress manifest themselves in duodenal ulcer whereas other types manifest themselves in different physiological disorders? Why during the period of "early urbanisation" should the most urbanised (the upper classes) have suffered to a greater extent than the workers (whose adjustment to industrialisation must have been considerable)? Why, after several decades of industrialisation and urban living, should young members of the working class (who were probably born and bred in town) have an increased incidence of duodenal ulcer? And what, as Susser puts it in a later paper, ${ }^{78}$ are "the causes which reside in the urbanising process?"

In so far as the industrial development and population growth of Johannesburg resembles what occurred in Britain some decades earlier, we could postulate a similar pattern of the prevalence of duodenal ulcer. If this were so we would, following Susser, be able to make the following general predictions. Firstly, in the early phases duodenal ulcer would occur most often among the English-speaking and immigrant whites who established and ran the new industries. Secondly, there would be a low incidence among those who constituted the white lower working class and among black and coloured people, who made up the lowest segment of the working class. Thirdly, there would be a gradual fall in the prevalence of the disease among the upper classes and an increase among the upper working class and emerging middle class. Initially this would affect mainly whites. Finally, as blacks rose into the higher working and middle classes, the incidence of duodenal ulcer would increase.

While there are no data on the changes in the prevalence of duodenal ulcer among other South African populations, our findings suggest that blacks are showing the pattern we have postulated. But, as Susser has not offered any explanation for what has occurred in Britain we have no clue about how we might understand an apparently similar pattern among Johannesburg blacks. Indeed the facts seem contrary to common-sense expectation: during the early period of urbanisation, it is the vast numbers of migrants from the small villages and rural areas who are subjected to the greater pressures. Thus the black immigrant leaves a rural tribal sociocultural milieu for the multiethnic Western environment of the city; he moves from a subsistence economy into one requiring new skills, new concepts of time, new work attitudes, and different kinds of work relationships; he is removed from the close neighbourliness of a rural community to the anonymity of city life; and his residential arrangements, his family life, and his physical environment are all very different from those in the countryside. One might therefore reasonably expect that migrants would be subjected to tremendous stresses and strains and that, in so far

TABLE VII-Anxiety in patients with duodenal ulcer and their unmatched controls compared with that in African miners. Anxiety was assessed by the Taylor Manifest Anxiety test

\begin{tabular}{|c|c|c|c|c|c|c|c|c|c|c|c|c|c|c|}
\hline Anxiety score: & $\begin{array}{c}0 \\
\text { (low) }\end{array}$ & 1 & 2 & 3 & 4 & 5 & 6 & 7 & 8 & 9 & 10 & $\begin{array}{c}11 \\
\text { (High) }\end{array}$ & Total & Mean \pm SD \\
\hline 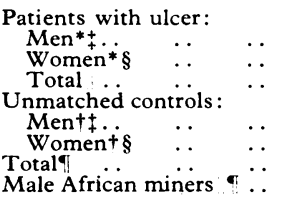 & $\begin{array}{r}2 \\
2 \\
1 \\
1 \\
23\end{array}$ & $\begin{array}{l}1 \\
1\end{array}$ & $\begin{array}{r}1 \\
1 \\
1 \\
1 \\
37\end{array}$ & $\begin{array}{r}1 \\
1 \\
1 \\
1 \\
33\end{array}$ & $\begin{array}{r}2 \\
2 \\
1 \\
2 \\
3 \\
25\end{array}$ & $\begin{array}{r}1 \\
1 \\
3 \\
2 \\
5 \\
32\end{array}$ & $\begin{array}{r}1 \\
3 \\
4 \\
45\end{array}$ & $\begin{array}{r}3 \\
3 \\
3 \\
3 \\
69\end{array}$ & $\begin{array}{r}2 \\
2 \\
2 \\
1 \\
3 \\
19\end{array}$ & $\begin{array}{r}1 \\
2 \\
3 \\
4 \\
4 \\
7 \\
21\end{array}$ & $\begin{array}{r}5 \\
1 \\
6 \\
8 \\
9 \\
17 \\
20\end{array}$ & $\begin{array}{r}1 \\
2 \\
3 \\
8 \\
8 \\
15 \\
23 \\
15\end{array}$ & $\begin{array}{r}13 \\
12 \\
25 \\
33 \\
35 \\
68 \\
360\end{array}$ & $\begin{array}{l}6.92 \pm 4 \cdot 25 \\
7 \cdot 16 \pm 2.94 \\
7 \cdot 04 \pm 3 \cdot 61 \\
8 \cdot 21 \pm 2.96 \\
9 \cdot 31 \pm 2 \cdot 27 \\
8.77 \pm 2.67 \\
4.92 \pm 2 \cdot 85\end{array}$ \\
\hline
\end{tabular}

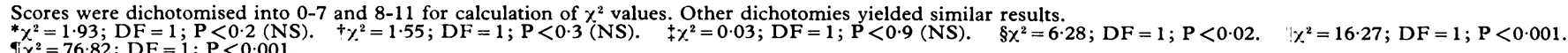


as duodenal ulcer is associated with stress, the disease would be highly prevalent among them. The facts are contrary to expectation: thus on the one hand Geddes ${ }^{9}$ reports only two cases in five years among 18622 black migrant mineworkers admitted to hospital, while our findings show that the main sufferers from duodenal ulcer are the younger, urbanised, educated men in the higher employment categories.

A possible explanation for both our observations and those of Susser in Britain is that where the need to make considerable adjustments is shared by a large proportion of a population stress may be reduced and adaptation facilitated. As certain individuals gain in skill and proficiency and exhibit certain talents and characteristics, however, they become upwardly mobile. Not only do they find themselves with greater responsibilities on the job, but they must also adjust to other aspects of their new roles. Those who cannot cope with these new stresses cannot, however, find comfort with the mass of their fellows since they have moved upwards out of their ranks. This might explain why Dunn and $\mathrm{Cobb}^{10}$ found a high rate of peptic ulcer among foremen, and why the blacks in our sample were clearly upwardly mobile into the higher ranks of the working class.

In conclusion, we must emphasise that our study was no more than a preliminary exploration of a field in which sophisticated and reliable epidemiological research is sadly lacking and where assumptions are often groundless. The question of the relation between stress and duodenal ulcer remains a matter for considerable research, as does the question raised by Susser's data on why certain types of stress manifest themselves in duodenal ulcers while others do not.

The population figures for blacks in Johannesburg were derived $\underline{\underline{T}}$ from provisional unpublished results of the 1970 official population $>$ census, by courtesy of the Department of Statistics, Pretoria. We $\mathbb{D}$ thank Mr David White for providing the adapted Taylor anxiety scale and the preliminary results of his study among black miners, and the superintendent, Baragwanath Hospital, for permission to publish. Finally, we are indebted to the Stella and Paul Loewenstein Trust for a grant to the African Studies Institute.

\section{References}

Campbell, G D, Seedat, Y K, and Daynes, G, Clinical Medicine in $\overrightarrow{0}$ Africans in Southern Africa. Churchill Livingstone. Edinburgh and London, 1973.

2 Beyers, C F, Fournal of the Medical Association of South Africa, 1927, 1, 606.

${ }^{3}$ Eagle, P C, and Gillman, J, South African fournal of Medical Science, $1938,3,1$.

${ }^{4}$ Bremner, C G, South African fournal of Surgery, 1971, 10, 139.

5 Taylor, J A, fournal of Abnormal and Social Psychology, 1953, 48, 285.

6 Department of Statistics, Population Census 1970 Report No 02-05-10, Government Printer. Pretoria, 1976.

7 Susser, M, and Stein, Z, Lancet, 1962, 1, 1115.

${ }^{8}$ Susser, M, Fournal of Chronic Diseases, 1967, 20, 435.

${ }^{9}$ Geddes, E W, personal communication, 1977.

${ }^{10}$ Dunn, J P, and Cobb, S, Fournal of Occupational Medicine, 1962, 4, 343. N

(Accepted 1 December 1977)

\title{
Coronary heart disease in relation to age, sex, and the menopause
}

\author{
R F HELLER, H S JACOBS
}

British Medical fournal, 1978, 1, 472-474

\section{Summary and conclusions}

Examination of the Registrar General's mortality data suggested that women do not lose protection from coronary heart disease (CHD) after the menopause. Apparently, at around the age of 50 men begin to lose a factor that had previously put them at increased risk of developing CHD compared with women. Male sex hormones may be risk factors for CHD, and further studies are needed to clarify their role in the aetiology of CHD in men.

\section{Introduction}

Men are more likely to develop coronary heart disease (CHD) than women. After the age of 50 the difference between men and women in the mortality rate from CHD diminishes until the age of 80 or more, when death rates from CHD are similar in both. ${ }^{1}$ Many have thought that young women are protected from CHD by ovarian hormones, and that they lose this protection after the

St Mary's Hospital Medical School, London W2 1PG R F HELLER, MD, MRCP, lecturer in medicine and epidemiology H S JACOBS, MD, MRCP, senior lecturer in obstetrics and gynaecology menopause, when concentrations of these hormones are reduced. If this were so the rate at which women die of CHD after the menopause would be accelerated. We have examined the differences between men and women in mortality from CHD to test the consistency with this and other hypotheses.

\section{Methods and results}

Figure 1 shows the death rates from CHD in men and women (coded as ischaemic heart disease, International Classification of Diseases (ICD) categories 410-414, by the Registrar General of England and N Wales) averaged over the most recent five years for which figures $N$ were available (1970-4). A semilogarithmic scale was used to compare the proportionate change from one age group to the next. When examining the relation between CHD death rates and age, single 0 straight lines were found not to fit the data well, but for both men and women there was a curvilinear relation (obtained by fitting a quadratic $\stackrel{\mathcal{P}}{\rightarrow}$ equation to the data). To examine any change in death rates at the 0 time of the menopause straight lines were fitted for age groups below 50 (the median age of the menopause in the $\mathrm{UK}^{2}$ ) and 50 and above. Two such lines appeared to fit the data as well as the single curve over the whole age span in both men and women. The slope of the line for women (fig 1) was a little less steep above 50 years than below, showing that there was no acceleration in the increase of CHD death rates after 8 the menopause. Although in each age group the death rates were higher in men, below the age of 50 the rates of increase (that is, the slopes) were similar for both sexes. After the age of 50 the rate of increase in men was much lower than it was both in younger groups of men and in women. Apparently a change occurred around the time of the menopause, but it was in men rather than women.

Figure 2 shows that this difference between men and women clearly 